\title{
Entrepreneurial self-efficacy and intention among Vietnamese students: A meta-analytic path analysis based on the theory of planned behaviour
}

\author{
Duong Cong Doanh ${ }^{a^{*}}$ and Tran Van Trang ${ }^{b}$
}

${ }^{a}$ Faculty of Business Management, National Economics University, Vietnam

${ }^{b}$ Faculty of Business Administration, Thuongmai University, Vietnam

\section{H R O N I C L E}

\section{Article history:}

Received: April 272019

Received in revised format: May

102019

Accepted: June 9, 2019

Available online:

June 9, 2019

Keywords:

Entrepreneurial self-efficacy

Entrepreneurial intention

Theory of planned behaviour

\section{A B S T R A C T}

This study develops a mediated model to investigate the relationship between entrepreneurial selfefficacy and entrepreneurial intention among Vietnamese students. This model also focuses on examining the role of subjective norms on shaping entrepreneurial intention. By using a meta-analytic path analysis with a sample of 2218 students at 14 universities in Vietnam and based on the theory of planned behaviour, authors find that subjective norms did not directly influence on entrepreneurial intention but it had strong indirect effect on entrepreneurial intention through entrepreneurial self-efficacy, attitude toward entrepreneurship and perceived behavioural control. Moreover, the relationship between self-efficacy and entrepreneurial intention was also mediated by attitude towards entrepreneurship and perceived behavioural control. In terms of direct effect, the result illustrates that attitudes towards entrepreneurship had the strongest effect on entrepreneurial intention among Vietnamese students, followed by entrepreneurial self-efficacy. These findings also show that the theory of planned behaviour could be effectively applied in the context of transitional economics in Vietnam.

\section{Introduction}

Entrepreneurial intention has been an imperative research topic in entrepreneurship. Scholars following the cognitive approach argue that intention plays a very relevant role in the decision to start a new business (Bird, 1998; Kolvereid, 1996a,b; Krueger, 1993; Krueger et al., 2000; Liñán \& Chen, 2009; Tsai et al., 2014; Krueger \& Brazeal, 1994). A numerous works have been published about this issue. However, many studies are still needed to better comprehend what factors affect the entrepreneurial perceptions and intention and why the importance of the factors explaining intention differs among different cultures (Liñán \& Chen, 2009; Tran, 2011). Among several factors found to have a direct and indirect effect on entrepreneurial intention, the results do not seem to be very clear regarding entrepreneurial self-efficacy and subjective norms. In fact, many researchers argue that entrepreneurial self-efficacy was identified as a crucial factor and the best predictor to explore an individual' entrepreneurial intention and success (Tsai

* Corresponding author.

E-mail address: doanhdoanh.qtkd.neu@gmail.com (D. Cong Doanh) 
et al., 2014; Krueger et al., 2000; Liñán, 2008). The previous studies contributed substantially to entrepreneurial literature; however, questions regarding the effect of self-efficacy on the entrepreneurial intention are not still clearly answered (Tsai et al., 2014). In addition, personal beliefs are people's abilities to carry out a particular behaviour effects on perceived behavioural control and attitudes toward behaviour, thus influencing the intention to perform this behaviour (Ajzen, 1991). Thus, the effects of entrepreneurial efficacy on business start-up intention through perceived behaviour control and attitudes toward entrepreneurship must be considered.

Furthermore, subjective norms, which reflects the expectations of salient people in terms of carrying out an individual' particular behaviour, may influence people's self-efficacy. However, a volume of scholarly research has agreed that the link between subjective norms and intention to perform a particular behaviour is still not clearly proved (Autio et al., 2001; Liñán \& Chen, 2009; Miranda et al., 2017). As a result, it is necessary to do further research to investigate whether subjective norms has direct and indirect impacts on entrepreneurial intention through self-efficacy.

This study aims to fill existing knowledge gaps in entrepreneurial literature by exploring two questions: (1) Do the relationships between Vietnamese students' entrepreneurial self-efficacy and intention are mediated by attitudes toward entrepreneurship and perceived behavioural control? (2) How do subjective norms influence on Vietnamese students' entrepreneurial intention? In addition to direct influence, whether subjective norms indirectly influence on entrepreneurial intention through entrepreneurial selfefficacy, attitudes towards entrepreneurship and perceived behavioural control?.

Contributions of this study to entrepreneurial literature are presented in three aspects. First, the mediating process of entrepreneurial self-efficacy to intention is investigated, while previous studies only focus on direct effect of entrepreneurial self-efficacy on intention (Chen et al., 1998; Markman et al., 2002; Segal et al., 2005), this study explores the indirect effect of self-efficacy on intention throughout attitudes toward entrepreneurship and perceived behavioural control. Secondly, whereas relevant studies only investigate the direct influence of subjective norms on entrepreneurial intention (Liñán et al., 2013; Miranda et al., 2017), this study investigates both the direct and moderating effect of subjective norm. Finally, this study enhances the knowledge of entrepreneurial literature by adopting the planned behavioural theory to the university context of Vietnam.

This study is organized in as follows: First, literature review, conceptual framework and hypotheses involving the link of entrepreneurial self-efficacy, subjective norm and intention are presented. Second, research methods including data collection, analyses and measures are discussed. After that, the research results are represented. Finally, conclusion and recommendation for further researches are performed at the final part.

\section{Literature review and hypotheses}

Fig. 1 describes the conceptual framework of the proposed study. By adopting the planned behavioural

theory and self-efficacy theory, authors examine the relationship between entrepreneurial self-efficacy and entrepreneurial intention. Bandura et al. (1980) argued that an individual's beliefs to effectively achieve a specific task strongly effects to his/her intention and behaviour whereas Ajzen (1991) suggested that a person's control belief not only influences on attitudes toward behaviour and perceived behavioural control but it also effects on his/her intention and behaviour. Thus, besides a direct relationship between entrepreneurial efficacy and entrepreneurial intention, entrepreneurial intention is indirectly influenced by entrepreneurial self-efficacy through attitudes towards entrepreneurship and perceived behavioural control. In addition, this study also investigates both direct and indirect effects of subjective norms on entrepreneurial intention. Based on literature review, the conceptual framework was implemented to develop research hypotheses. 


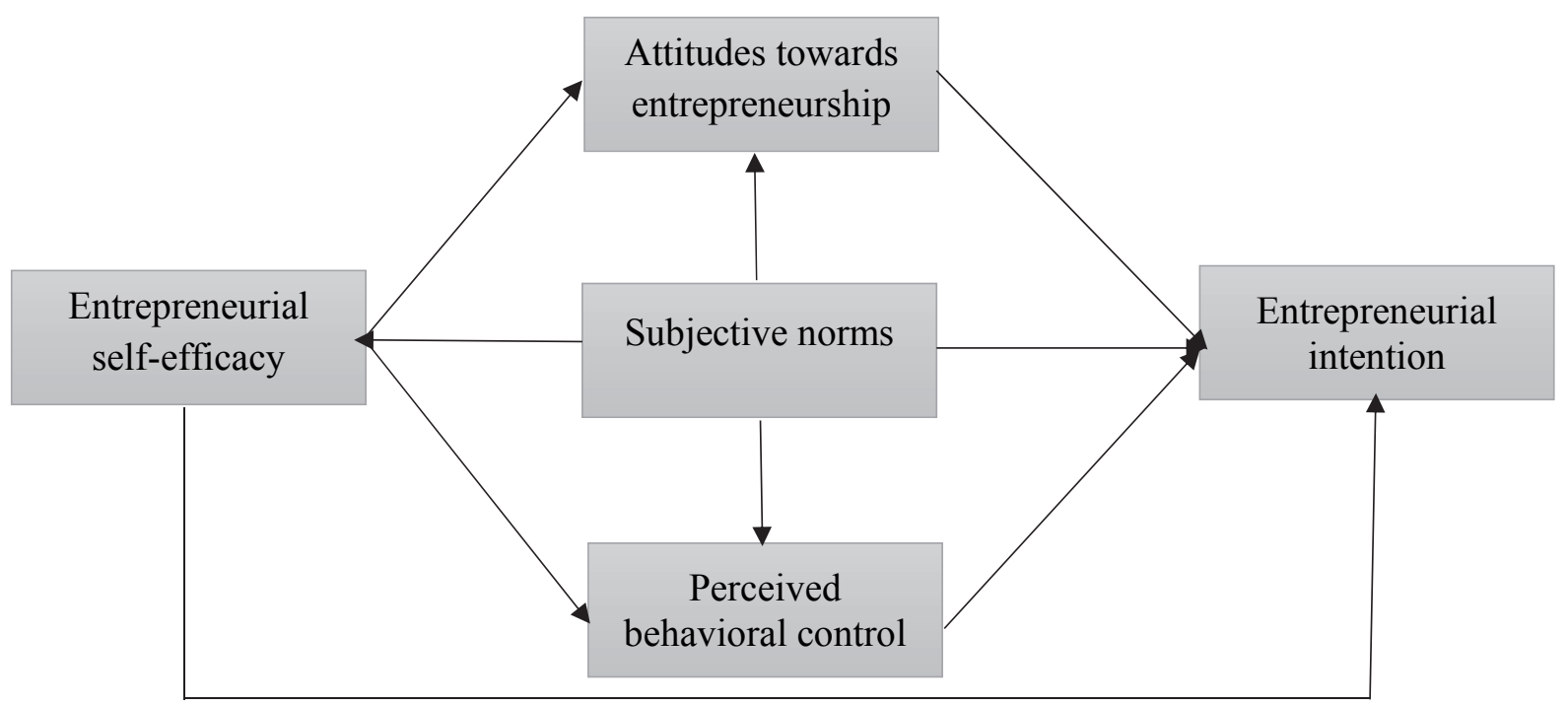

Fig. 1. Conceptual framework

\subsection{The roles of three components in the theory of planned behaviour}

The theory of planned behavior probably can be implemented to any behavior which requires particular amount of planning. Thus, this theory has been reliably proved to be robust in explaining intentions and behavior in various fields of research. The decision to become an entrepreneur is a complex one, it is also seen as the result of intricate mental processes. Based on this sense, the theory of planned behavior of Ajzen (1991) has been frequently applied to explain this mental process leading to firm creation (Liñán, 2008). The roles of three components, including attitudes towards entrepreneurship, subjective norms and perceived behavioural control, in the theory of planned behaviour in shaping entrepreneurial intention has been considered in a volume of studies (Kolvereid, 1996a). However, the direct link between subjective norm and entrepreneurial intention is still not clearly explained. Some researches stated that entrepreneurial intention can be significantly explained by subjective norms (Kolvereid, 1996a; Kolvereid \& Isaksen, 2006), while others argued that there is no relationship between subjective norms and entrepreneurial intention (Autio et al., 2001; Krueger et al., 2000). Thus, Krueger at al. (2000) believed that this relationship should be consider in the further researches. Some studies illustrated that entrepreneurial intention was not influenced by subjective norms (Liñán, 2008; Nabi \& Liñán, 2013). However, family, friends and teachers can affect strongly on students' career choice in the cultural context of Vietnam, the following hypotheses are proposed.

H1a. Entrepreneurial intention is positively related to attitudes toward entrepreneurship.

H1b. Entrepreneurial intention is positively related to subjective norms.

H1c. Entrepreneurial intention is positively related to perceived behavioural control.

\subsection{The role of entrepreneurial self-efficacy}

Self-efficacy reflects individual's perception of his/her ability and necessary skills to perform a specific task to control or manage issues (Bandura, 1977, 1986, 2001). Nwanzu and Babalola (2019) stated that self-efficacy shows a belief in one's abilities to perform a specific task. It is believing and seeing oneself as being able to deal with the challenges of life. In other words, self-efficacy reflects a person's belief in terms of whether they can perform a particular behaviour or not (Lopez \& Snyder, 2011).

Entrepreneurial self-efficacy has been defined by scholars from different perspectives. Some researchers have defined entrepreneurial self-efficacy as entrepreneurs' self-confidence in terms of carrying out a 
specific task (Baum et al., 2001; Baron et al., 1999) while others have described entrepreneurial selfefficacy as an individual's confidence in his/her ability to accomplish the entrepreneurial process (Chen et al.,1998; Segal et al., 2005; Tsai et al., 2014).

Entrepreneurial self-efficacy and perceived behavioural control are two distinct constructs distinguished in many researches (Tsai et al., 2014; Tavousi et al., 2009). Indeed, while control beliefs are considered as individual's belief in terms of the presence of factors that are able to help in carrying out a behaviour, perceived behavioural control relates to whether an individual perceives carrying out a specific task very easily or with difficulty (Ajzen, 1991). In this study, authors adopt the later perspective to consider this construct.

The relationship between entrepreneurial self-efficacy and intention have been investigated in many previous studies. For instance, when undergraduate and graduate students have a high self-efficacy, they also have high intention in regard to engage in entrepreneurship (Chen et al. 1998; Kickul et al., 2009; Liñán et al., 2011; Shinnar et al., 2014; Utamin, 2017; Saraih et al., 2018) and even high entrepreneurial behaviour (Neto et al., 2018). In addition, there are different results performed in various countries (Krueger et al., 2000; Baugh et al., 2006; Miranda et al., 2017; Saraih et al., 2018). In other words, the influential level of self-efficacy on business start-up intention depends on each specific context. However, there are lack of studies investigating the indirect effect of entrepreneurial self-efficacy on start-up intention (Miranda et al., 2017), specially throughout three components of the planned behavioural theory.

One of the contribution of the self-efficacy theory is to discover the links among belief, attitude, intention and behaviour. Bandura et al. (1980) stated that an individual's intention and behaviour are significantly influenced by the belief of his/her ability to perform this specific task effectively whereas the theory of planned behaviour also argued that perceived behavioural control and attitude towards behaviour are affected by people's control belief (Ajzen, 1991). A person' belief may influence on his or her intention and behaviour and an individual's attitude towards behaviour can be effected by his or her belief of the results of this particular behaviour. A person, who has high beliefs of ability to perform a specific task, can have high intention to touch this particular achievement (Bandura, 1977; Bandura et al., 1980). Thus, an individual's entrepreneurial self-efficacy can influence on his or her attitude toward entrepreneurship.

H2a. Attitude toward entrepreneurship is positively related to entrepreneurial self-efficacy.

Perceived behavioural control refers to the extent to which a personal control belief in terms of the activities being studied (Solesvik et al., 2012), while Liñán \& Chen (2006, p.4) defined perceived behavioural control as "the perception of easiness or difficulty in the fulfilment of the behaviour of interest". This construct consists of not only being able to have the essential skills to run a business and achieve success (Miranda et al., 2017), but also the perception about controllability of the behaviour (Liñán \& Chen, 2009). Entrepreneurship research emphasizes the importance of perceived behavioural control as a mechanism for overcoming awareness of the greater technological, financial, legal uncertainties which are often related to new ventures (Obschonka et al., 2010; Silveira-Perez et al., 2016). Schlaegel and Koenig (2014) consider that controllability perception has positive effect on the intention to become a founder. Ajzen (1991) divided perceived behavioural control into two components, which include the availability of resources required to conduct the behaviour and the focal individual's self-confidence in the capacities to perform the behaviour. In addition, Ajzen and Code (2008) argued that perceived behavioural control is identified by control beliefs involving in the availability of factors (market opportunities, resources, role models, social capitals) which might facilitate or impede performance of behaviour. According to the theory of planned behaviour, perceived behavioural control is related to an individual's perception in terms of the difficulty in performing a specific behaviour. Also, based on the theory of planned behaviour, a person's perceived behavioural control and attitude toward behaviour can be determined through his or her belief control (Ajzen, 1991). Liñán (2008) believed that if a person has strong self-efficacy of running a business, he or she can perceive the low risk in terms of performing business start-up. Thus, people, who have high entrepreneurial self-efficacy, can have high level of willingness to 
start a business. In other word, entrepreneurial self-efficacy can influence perceived behavioural control positively.

H2b. Perceived behavioural control is positively related to entrepreneurial self-efficacy.

A person's entrepreneurial self-efficacy is seen as his or her perception of ability to start a business and entrepreneurial intention can be influenced by entrepreneurial self-efficacy (Chen et al., 1998). Bandura (1997) stated that a person has high self-efficacy can show higher capacity to follow and reach achievement. Therefore, entrepreneurial self-efficacy is also seen as an effective predictor to explain entrepreneurial intention and behaviour, it also plays an important role in determining choices, effort, patient to reach achievement (Chen et al. 2004). In addition, Lee et al. (2011) states that a person's entrepreneurial self-efficacy is considered as a key factor to predict his or her entrepreneurial intention while Krueger et al. (2000) also consider that entrepreneurial self-efficacy can have direct and indirect effects on entrepreneurial intention. Thus, hypotheses are proposed to investigate the relationship between entrepreneurial self-efficacy and entrepreneurial intention among Vietnamese students.

H2c. Entrepreneurial intention is positively related to entrepreneurial self-efficacy.

\subsection{The role of subjective norms}

Subjective norms reflect the perceived social pressure in terms of performing or not performing the particular behaviour (Ajzen, 1991). In entrepreneurial studies, subjective norms refer to an individual's perceptions of salient people, including family, friends, relatives and reference others, who would or would not approve of the decision to run his or her own business (Liñán, 2008). In addition, based on perspectives of both internal and external motivation, subjective norms are also seen as one of the context factor, which can have positive or negative effects on entrepreneurial self-efficacy and entrepreneurial intention as well. A person's entrepreneurial self-efficacy may increase in case of significant people approving his or her decision to become an entrepreneur but if salient others would not approve this decision, his or her entrepreneurial self-efficacy can be lower. Thus, the link between subjective norms and entrepreneurial self-efficacy is investigated in the following hypotheses.

H3a. Entrepreneurial self-efficacy is positively related to subjective norms.

Subjective norms are considered a factor affecting on attitude towards behaviour since an individual's attitude towards performing a specific task is influenced by his or her perceived expectations about salient people, who would or would not approve of the intention to become an entrepreneur. In entrepreneurship researches, a person has negative attitude towards entrepreneurship if reference people approve and support, his or her attitude towards entrepreneurship may become more positive. In addition, the strong correlation between subjective norms and attitude towards entrepreneurship has been discovered in some previous studies (Al-Rafee \& Cronan, 2006). Thus, this relationship is more clearly proved in our study.

H3b. Attitude towards entrepreneurship is positively related to subjective norms.

Perceived behavioural control refers beliefs of start-up skills, business knowledge and opportunity. Bandura (1986) state that social beliefs play an important role in shaping an individual's personal beliefs of ability to perform a specific behaviour. A person can be convinced to believe that he or she has enough skills, knowledge and ability to reach an achievement successfully. For instance, the verbal encouragement of "I know you will succeed" from reference people can help an individual to remove self-doubt and focus on his or her effort on performing a behaviour (Bandura, 1977). Thus, the encouragement of salient others can have dramatic effects on one's capacity beliefs.

H3c. Perceived behavioural control is positively related to subjective norms. 


\section{Methods}

\subsection{Survey and sample}

The surveys are divided into 2 sections, which is based on the purpose of the study, theoretical background and hypotheses. In the first section, the questions are designed to allow respondents providing their viewpoint regarding entrepreneurial self-efficacy, attitude toward entrepreneurship, subjective norms, perceived behavioural control and entrepreneurial intention, which was adapted from the previous studies. In the second section, demographic questions are designed to obtain respondents' information such as gender, fields of study and type of current professional (working) activities. Final-year undergraduate students at universities in Vietnam are chosen as the sample in our study. Liñán and Chen (2009) state that samples of students are relatively popular in entrepreneurship researches (Autio et al, 2001; Fayolle et al., 2006; Krueger et al. 2000). Reynolds et al. (2002) also argue that undergraduate students, who are from 25 to 34, have the highest intention to start a business. 2500 questionnaires were directly distributed to final undergraduate students at 14 universities in three regions of Vietnam (North, Central and South), including face-to-face explanations about the research's objectives and instructions on how to complete questionnaires, but only 2218 questionnaires are collected (approximately 88.72\%). The rest of samples ( 282 questionnaires) are removed because of being not adequately fulfilled. Demographic information of respondents is presented in Table 1.

Table 1

Descriptive Statistics of Sample Demographics

\begin{tabular}{llllll}
\hline \multicolumn{2}{c}{ Demographic variables } & F & $\%$ & Mean & Std. Deviation \\
\hline 1. Gender & Male & 1384 & 62.4 & 1.3760 & 0.48449 \\
& Female & 834 & 37.6 & & \\
\hline 2. Fields of study & Economics & 1221 & 54.6 & 1.4536 & 0.49795 \\
& Non-economics & 1006 & 45.4 & & \\
\hline 3. Type of current & Only studying & 699 & 31.5 & 2.0798 & 1.02095 \\
$\begin{array}{l}\text { professional } \\
\text { (working) }\end{array}$ & $\begin{array}{l}\text { Studying and working for a } \\
\text { activities }\end{array}$ & 1080 & 45.9 & & \\
& $\begin{array}{l}\text { Studying and running own busi- } \\
\text { ness }\end{array}$ & 126 & 5.7 & & \\
& Studying and looking for a job & 375 & 16.9 & & \\
\hline
\end{tabular}

Note: $\mathrm{N}=2218$; F: Frequency; \%: Percent

Source: Authors' elaborations based on research study

The results of descriptive statistics of demographic layouts indicate that the large proportion of respondents is male, accounting for $62.4 \%$ while only $37.6 \%$ of respondents are female. In terms of fields of study, approximately $55 \%$ students study economics whereas non-economics students only account for $45.4 \%$. In addition, $16.9 \%$ students consider that they are studying and looking for a job, $31.5 \%$ students are only studying, $45.9 \%$ students are studying and working for a company, and only $5.7 \%$ of them are studying and running a business.

\subsection{Analyses}

We performed a regression analysis to assess the contributions of entrepreneurial self-efficacy to entrepreneurial intention and examine the roles of subjective norms to shape entrepreneurial self-efficacy and entrepreneurial intention. Structural equation modelling (SEM) was implemented to test the hypothesized relationships and analysis process includes three main steps. First, Cronbach's alpha and explorative factor analysis (EFA) are implemented to assess the reliability of variables. Secondly, confirmatory factor analysis (CFA) is employed to test the empirical validity of the research model and each measure. Finally, the structural equation modelling was then applied to estimated path coefficients for each proposed relationship in the conceptual framework. In addition, the statistical analysis has been carried out using SPSS 22.0 and AMOS 22.0 software. 


\subsection{Measures}

All scales used in our study were adapted from the past researches including entrepreneurial self-efficacy (Liñán, 2008; Tsai et al., 2014), attitude towards entrepreneurship (Liñán \& Chen, 2009), subjective norms (Liñán \& Chen, 2009; Kolvereid, 1996b), perceived behavioural control and entrepreneurial intention (Liñán \& Chen, 2009). The scales were scored on a 5-point Liker-type format from strongly disagree to strongly agree. All scales were subjected to exploratory factor analysis (EFA) and confirmatory factor analysis (CFA) for the purpose of scale testing and purification.

Entrepreneurial self-efficacy (Cronbach's alpha $=0.840$ ): the scale consisted of 5 items. Two first items were adapted from Liñán (2008), including "I show great aptitude for creativity and innovation" $(0.840)$ and "I show great aptitude for leadership and problem-solving" $(0.802)$. The last three items were modified from Tsai et al. (2014), consisting of 'I can develop and maintain favourable relationships with potential investors' (0.796), 'I can see new market opportunities for new products and services' (0.789), and 'I can develop a working environment that encourages people to try out something new' $(0.890)$.

Attitude towards entrepreneurship (Cronbach's alpha =0.826): The scale developed by Liñán and Chen (2009), which is comprised of 5 items, including "Being an entrepreneur implies more advantages than disadvantages to me", "A career as an entrepreneur is attractive for me" $(0.780)$, "If I had opportunity and resources, I'd like to start a firm" (0.816), "Being an entrepreneur would entail great satisfactions for me" (0.759) and "Among various options, I would rather be an entrepreneur" (0.765). However, the corrected item-total correlation of the first item only reaches at $0.352<0.4$ (Nunally \& Brunstein, 1994). Thus, authors decided to remove this item from the scale of attitude towards entrepreneurship.

Subjective norms (Cronbach's alpha $=0.826$ ): The scale consisted of 3 items, two first items were developed by Liñán and Chen (2009), including "If I decided to create a firm, my closet family would approve of that decision" (0.827), "If I decided to create a firm, my closes friends would approve of that decision". However, authors suppose that almost all students who are not yet having a secure job can have no co-workers. Thus, the final item of "If I decided to create a firm, people who are important to me would approve of that decision" (0.792) was adapted from Kolvereid (1996b).

Perceived behavioural control (Cronbach's alpha $=0.822)$ : The scale developed by Liñán and Chen (2009), which consisted of 6 items, including "To start a firm and keep it working would be easy for me" $(0.805)$, "I am prepared to start a viable firm" $(0.775)$, "I can control the creation process of a new firm" (0.771), "I know the necessary practical details to start a firm" (0.788), "I know how to develop an entrepreneurial project" $(0.796)$ and "If I tried to start a firm, I would have a high probability of succeeding" (0.827).

Entrepreneurial intention $($ Cronbach's alpha $=0.918)$ : The construct was measured with Liñán \& Chen (2009) 6-item scale. Respondents indicate how interested they are in starting a new business, consisting of "I am ready to do anything to be an entrepreneur", "my professional goal is to become an entrepreneur", "I will make every effort to start and run my own firm" (0.911), "I am determined to create a firm in the future" (0.895), "I have a very seriously through of starting a firm" $(0.874)$ and "I have the firm intention to start a firm someday" (0.892). As the Cronbach's alpha of the first and second item are higher than that of the scale of entrepreneurial intention. Thus, authors had removed the first and second items from this scale.

\section{Results}

\subsection{Exploratory factor analysis (EFA)}

After assessing the reliability of scales by Cronbach's alpha, 22 items are used in the exploratory factor analysis (EFA). The first results of testing the reliability of scales by the exploratory factor analysis shows that $\mathrm{KMO}=0.926$, Sig. $($ Bartlett's Test $)=0.000<0.005$, Initial Eigenvalues $=66.986>50 \%$. However, factor loading of PBC6 (0.313), PBC5 (0.358) and ATE3 $(0.407)<0.5$ and loaded at two factor groups. 
Thus, authors decided to remove these items from scales before starting confirmatory. The final results of the exploratory factor analysis are presented at Table 2 .

\section{Table 2}

The results of exploratory factor analysis (EFA)

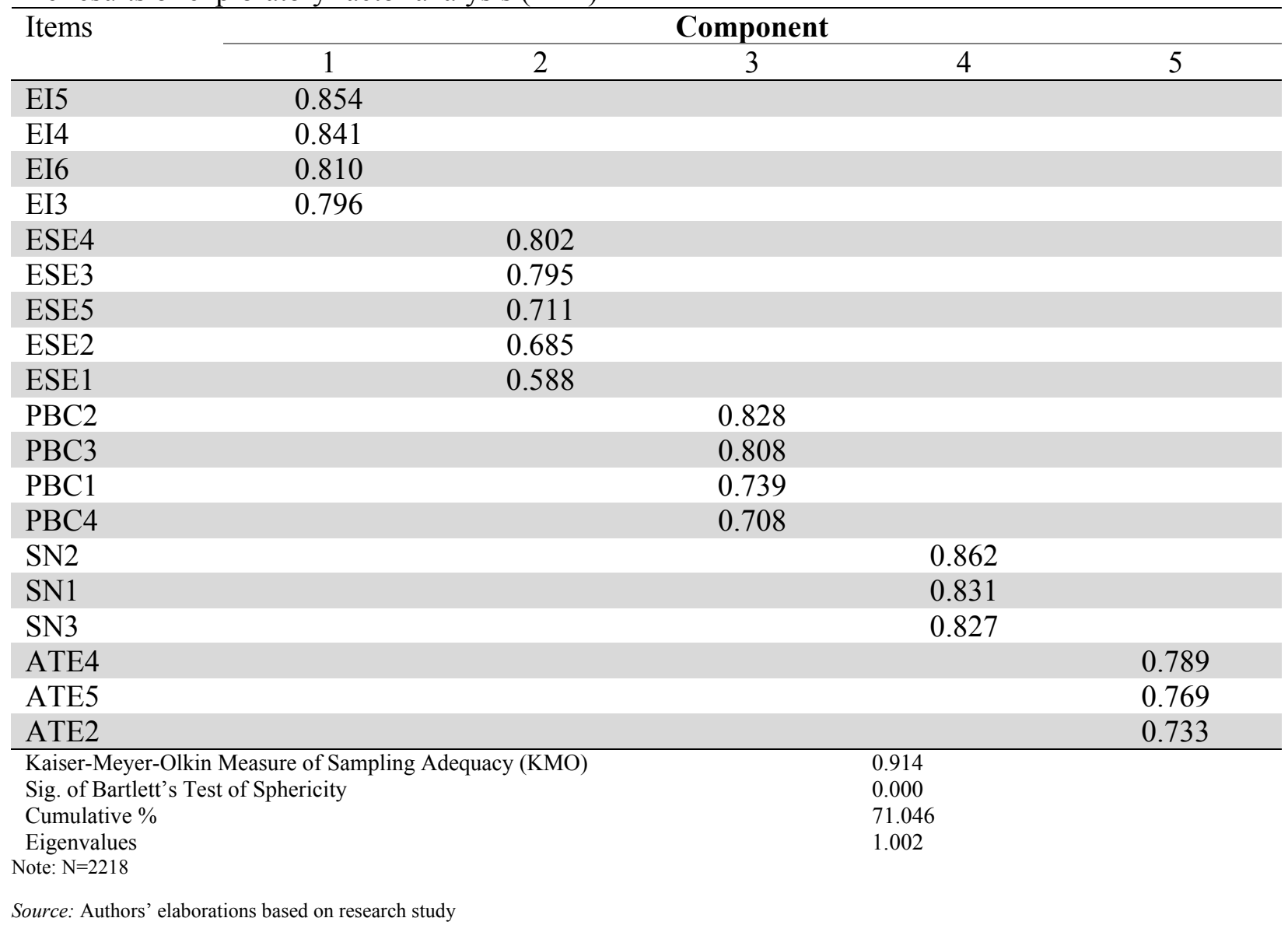

\subsection{Confirmatory factor analysis (CFA)}

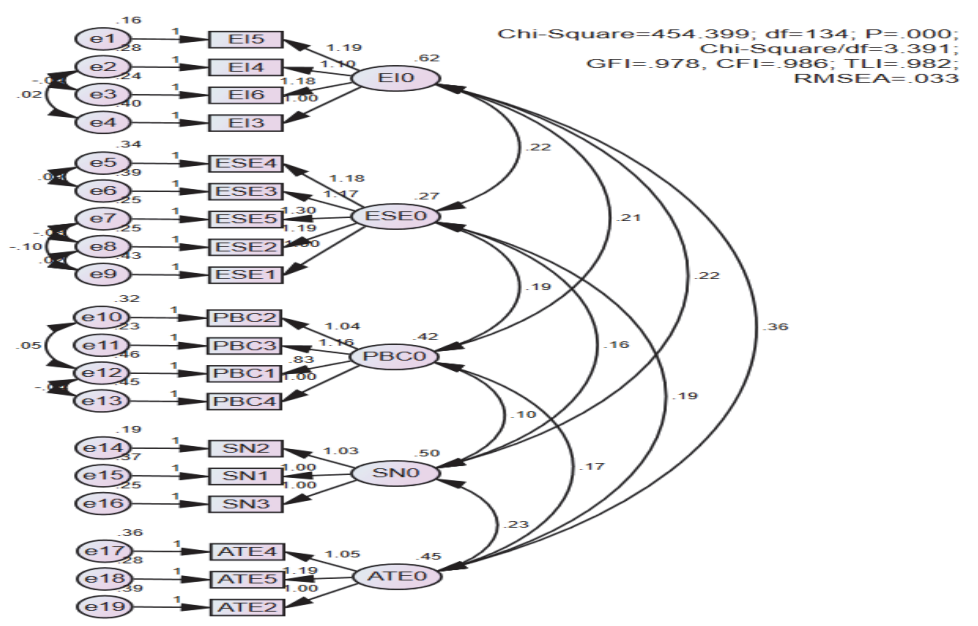

Note: $N=2218$

Source: Authors' elaborations based on research study

Fig. 2. The results of confirmatory factor analysis (unstandardized estimates) 
In order to assess measurement validity, the authors performed the confirmatory factor analysis (CFA) by using AMOS 22.0 (Hair et al., 1988). The results generally presented a good level of fit for the measurement models. After assessing each construct, the full measurement model was analysed at Fig.2. The results of CFA exhibited a reasonably good level of fit: $\chi^{2}(134)=454.399, p=0.000$. CMIN/df $=3.391$ $<0.5$ (Kettinger \& Lee, 1995), CFI $=0.986, \mathrm{GFI}=0.978, \mathrm{TLI}=0.982>0.9, \mathrm{RMSEA}=0.033$. Also, standardized regression weights of all items are higher than $0.5(\lambda>0.5)$. Thus, the convergent validity are determined at all scales. In addition, Table 3 shows the results of testing the discriminant validity between variables. The correlation of each couple of variables (r) and standard deviation (SE) are different to 1 (P-value $=0.000<0.005)$. Thus, the discriminant validity between variables are proved.

Table 3

The results of testing the discriminant validity between variables

\begin{tabular}{|c|c|c|c|c|c|c|c|}
\hline \multicolumn{3}{|c|}{ Relationship } & $\mathrm{r}$ & $1-r$ & SE & $\mathrm{CR}$ & P-value \\
\hline EI & $\leftrightarrow$ & $\overline{E S E}$ & 0.536 & 0.464 & 0.018 & 25.873 & 0.000 \\
\hline EI & $\leftrightarrow$ & PBC & 0.408 & 0.592 & 0.019 & 30.524 & 0.000 \\
\hline EI & $\leftrightarrow$ & SN & 0.395 & 0.605 & 0.020 & 31.001 & 0.000 \\
\hline EI & $\leftrightarrow$ & ATE & 0.685 & 0.315 & 0.015 & 20.354 & 0.000 \\
\hline ESE & $\leftrightarrow$ & PBC & 0.568 & 0.432 & 0.017 & 24.709 & 0.000 \\
\hline ESE & $\leftrightarrow$ & SN & 0.441 & 0.559 & 0.019 & 29.320 & 0.000 \\
\hline ESE & $\leftrightarrow$ & ATE & 0.54 & 0.460 & 0.018 & 25.728 & 0.000 \\
\hline $\mathrm{PBC}$ & $\leftrightarrow$ & SN & 0.222 & 0.778 & 0.021 & 37.561 & 0.000 \\
\hline PBC & $\leftrightarrow$ & ATE & 0.394 & 0.606 & 0.020 & 31.038 & 0.000 \\
\hline SN & $\leftrightarrow$ & ATE & 0.476 & 0.524 & 0.019 & 28.048 & 0.000 \\
\hline
\end{tabular}

Note: $N=2218$; $r$ : correlation; SE: Standard Deviation; $C R$ : Critical Ratios.

Source: Authors' elaborations based on research study

Table 4 shows the results of testing the measurement validity by confirmatory factor analysis. The results represent standardized regression weights $(\lambda)$, composite reliability $\left(\rho^{c}\right)$ and average variance extracted $\left(\rho^{\mathrm{vc}}\right)$ of all variables.

\section{Table 4}

The results of testing the measurement validity by confirmatory factor analysis

\begin{tabular}{|c|c|c|c|c|c|}
\hline Scales & Items & $\lambda$ & $\rho^{c}$ & $\rho^{\mathrm{vc}}$ & Assessment \\
\hline \multicolumn{2}{|c|}{ EI: Entrepreneurial intention } & 0.861 & 0.920 & 0.743 & reasonably good level \\
\hline EI6 & \multirow{4}{*}{4} & 0.886 & & & \\
\hline EI3 & & 0.782 & & & \\
\hline EI5 & & 0.919 & & & \\
\hline EI4 & & 0.855 & & & \\
\hline \multicolumn{2}{|c|}{ ATE: Attitude towards entrepreneurship } & 0.774 & 0.818 & 0.601 & reasonably good level \\
\hline ATE2 & \multirow{3}{*}{3} & 0.729 & & & \\
\hline ATE5 & & 0.833 & & & \\
\hline ATE4 & & 0.760 & & & \\
\hline \multicolumn{2}{|c|}{ SN: Subjective norms } & 0.813 & 0.854 & 0.662 & reasonably good level \\
\hline SN3 & \multirow[t]{3}{*}{3} & 0.820 & & & \\
\hline SN2 & & 0.861 & & & \\
\hline SN1 & & 0.757 & & & \\
\hline \multicolumn{2}{|c|}{ PBC: Perceived behavioural control } & 0.740 & 0.830 & 0.552 & reasonably good level \\
\hline PBC4 & \multirow[t]{4}{*}{4} & 0.697 & & & \\
\hline PBC1 & & 0.652 & & & \\
\hline PBC3 & & 0.827 & & & \\
\hline $\mathrm{PBC} 2$ & & 0.782 & & & \\
\hline \multicolumn{2}{|c|}{ ESE: Entrepreneurial self-efficacy } & 0.722 & 0.846 & 0.526 & reasonably good level \\
\hline ESE1 & \multirow[t]{5}{*}{5} & 0.597 & & & \\
\hline ESE4 & & 0.769 & & & \\
\hline ESE2 & & 0.707 & & & \\
\hline ESE5 & & 0.788 & & & \\
\hline ESE1 & & 0.749 & & & \\
\hline
\end{tabular}

Note: $N=2218$; $\lambda$ : Standardized Regression Weights; $\rho^{c}$ : Composite reliability (CR); $\rho^{v c}$ : Average Variance Extracted (AVE). Source: Authors' elaborations based on research study 


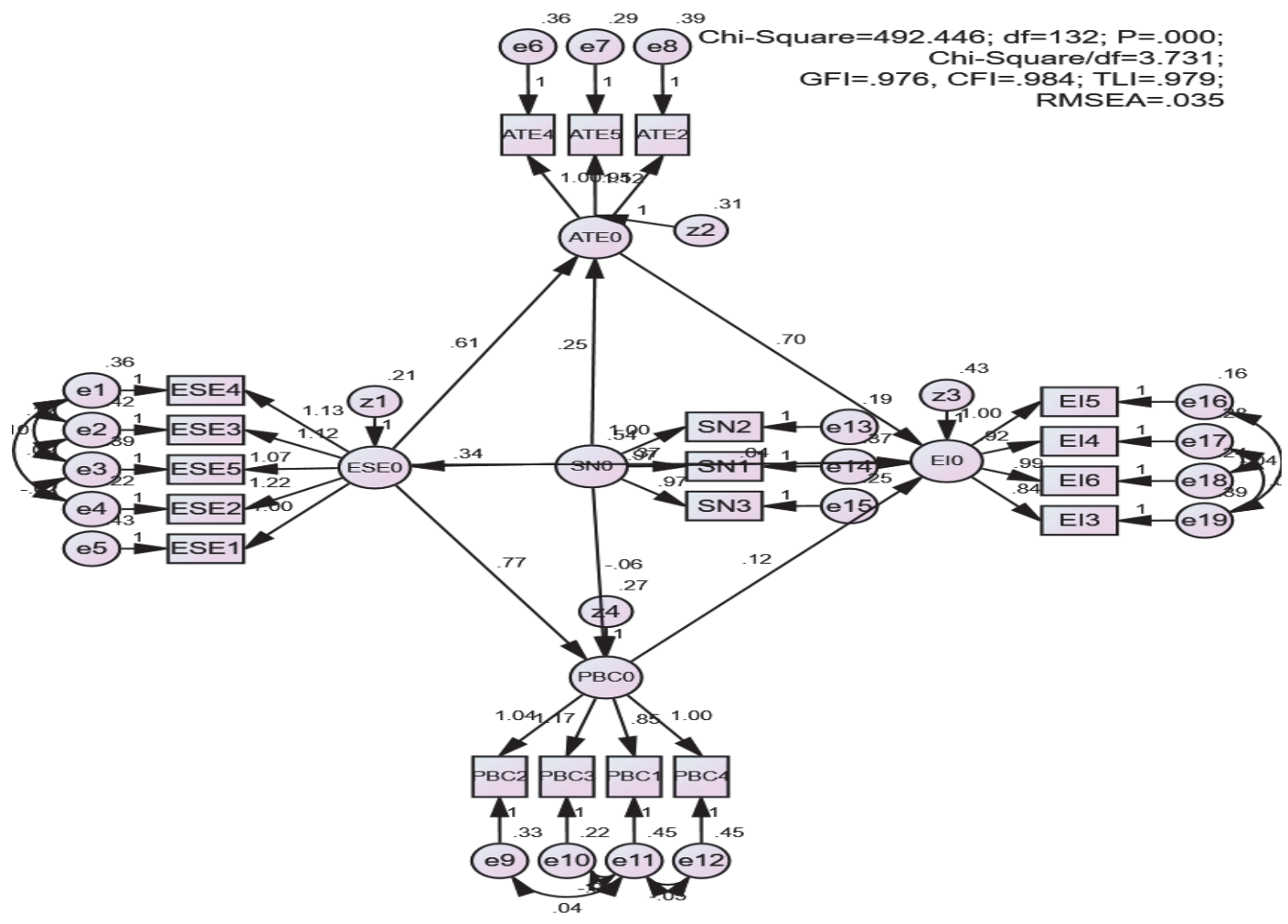

Note: $N=2218$

Source: Authors' elaborations based on research study

Fig. 3. The results of structural analyses (unstandardized estimates)

The overall fit statistics the model without the control variables illustrated an acceptable level of fit: $\chi^{2}$ $(134)=492.446, \mathrm{p}=0.000 . \mathrm{CMIN} / \mathrm{df}=3.731<0.5, \mathrm{CFI}=0.984, \mathrm{GFI}=0.976, \mathrm{TLI}=0.979>0.9$, RMSEA $=0.035$. So, the original model was used to test the hypothesized relationships.

Table 5

The results of testing the research hypotheses

\begin{tabular}{ccccccccc}
\hline \multicolumn{2}{c}{ Hypotheses } & & Estimate & S.E & C.R & P & Conclusion \\
\hline H1 & ATE & $\rightarrow$ & EI & 0.696 & 0.037 & 18.666 & $* * *$ & Supported \\
H2 & SN & $\rightarrow$ & EI & 0.036 & 0.029 & 1.230 & 0.219 & Rejected \\
H3 & PBC & $\rightarrow$ & EI & 0.124 & 0.124 & 0.036 & $* * *$ & Supported \\
H4 & ESE & $\rightarrow$ & ATE & 0.615 & 0.615 & 0.041 & $* * *$ & Supported \\
H5 & ESE & $\rightarrow$ & PBC & 0.770 & 0.770 & 0.044 & $* * *$ & Supported \\
H6 & ESE & $\rightarrow$ & EI & 0.369 & 0.060 & 6.192 & $* * *$ & Supported \\
H7 & SN & $\rightarrow$ & ESE & 0.343 & 0.020 & 17.193 & $* * *$ & Supported \\
H8 & SN & $\rightarrow$ & ATE & 0.249 & 0.026 & 9.710 & $* * *$ & Supported \\
H9 & SN & $\rightarrow$ & PBC & -0.065 & 0.024 & -2.743 & 0.006 & Supported \\
\hline
\end{tabular}

Note: $N=2218$; ***< 0.001; S.E: Standard Deviation ; C.R: Critical Ratios.

Source: Authors' elaborations based on research study.

A total of nine proposed relationships were tested. Eight of the nine hypothesized paths were statistically significant and only one hypothesis was rejected in the direction predicted. Specially, attitude towards 
entrepreneurship has the strongest effect on entrepreneurial intention $(\beta=0.696$; $p$-value $<0.001)$, followed by entrepreneurial self-efficacy $(\beta=0.369 ; p$-value $<0.001)$ and perceived behavioural control $(\beta=0.124$; $p$-value $<0.001)$ respectively. If only considering the direct effects, the relationship between entrepreneurial self-efficacy and perceived behavioural control is the strongest $(\beta=0.770$; $p$-value $<$ 0.001). Moreover, attitude towards entrepreneurship is rather strongly influenced by entrepreneurial selfefficacy $(\beta=0.615 ; 0.000<0.001)$. Analogously to many previous studies, the relationship between subjective norms and entrepreneurial intention is insignificant $(p$-value $>0.05)$. However, subjective norms dramatically influence on entrepreneurial self-efficacy $(\beta=0.343$; $p$-value $<0.001)$ and attitude towards entrepreneurship $(\beta=0.249 ; p$-value $<0.001)$. Interestingly, perceived behavioural control is negatively related to subjective norms $(\beta=-0.065 ; p$-value $<0.01)$.

In order to investigate the effect of factors on entrepreneurial intention, besides considering the direct relationship, this study has also discovered the indirect effect of variables on entrepreneurial intention. In terms of statistical method, researching the mediating impacts is considered as testing the effect of independent variable on dependent variable through mediators. In case of being a large sample, we can use the Sobel test to investigate these indirect effects (Sobel, 1986). However, Preacher and Hayes (2004, 2008) state that bootstrapping method should be applied because of being more effective if using original data. In our study, authors apply bootstrapping methods to discover the mediating effect of entrepreneurial self-efficacy and subjective norms on entrepreneurial intention.

The results of our study indicate that although entrepreneurial intention is not directly influenced by subjective norms, it is indirectly affected by subjective norms through entrepreneurial self-efficacy, attitude towards entrepreneurship and perceived behavioural control $\left(\beta_{\text {indirect } S N-E I}=0.471, p\right.$-value $\left.<0.001\right)$.

Table 6

Total effects of variables

\begin{tabular}{|c|c|c|c|c|c|}
\hline \multirow{2}{*}{$\begin{array}{l}\text { Dependent } \\
\text { variable }\end{array}$} & \multirow[t]{2}{*}{ Effects } & \multicolumn{4}{|c|}{ Independent variables } \\
\hline & & SN & ESE & ATE & PBC \\
\hline \multirow{3}{*}{ ESE } & Direct & 0.343 & & & \\
\hline & Indirect & 0.000 & & & \\
\hline & Total & 0.343 & & & \\
\hline \multirow[t]{3}{*}{ ATE } & Direct & 0.249 & 0.615 & & \\
\hline & Indirect & 0.211 & 0.000 & & \\
\hline & Total & 0.460 & 0.615 & & \\
\hline \multirow[t]{3}{*}{ PBC } & Direct & -0.065 & 0.770 & & \\
\hline & Indirect & 0.264 & 0.000 & & \\
\hline & Total & 0.199 & 0.770 & & \\
\hline \multirow[t]{3}{*}{ EI } & Direct & 0.000 & 0.369 & 0.696 & 0.124 \\
\hline & Indirect & 0.471 & 0.524 & 0.000 & 0.000 \\
\hline & Total & 0.471 & 0.893 & 0.696 & 0.124 \\
\hline
\end{tabular}

Note: $N=2218$

Source: Authors' elaborations based on research study.

Table 6 represents the total effects of variables. Firstly, the results of our study indicate that entrepreneurial intention is not directly influenced by subjective norms but attitude towards entrepreneurship have strongest influence on entrepreneurial intention $(\beta=0.696$; $p$-value $<0.001)$. This results reconfirmed the outcome of previous researches (Tran, 2011; Liñán, 2008; Maes et al., 2014). The research results indicate that the direct of self-efficacy is stronger than the direct impact of perceived behavioral control on business start-up intention ( $\beta=0.369$ and $\beta=0.124$ respectively). Thus, towards Vietnamese students, their beliefs of abilities and capacities to run a business is more important than their perception of easiness or difficulty in business start-up. This results also reconfirmed the difference between per- 
ceived behavioural control and self-efficacy. Secondly, entrepreneurial self-efficacy not only has the direct effects on entrepreneurial intention, but it also has very strong effects on perceived behavioural control and attitude towards entrepreneurship, $\beta=0,770$ and 0.615 respectively. The results are totally appropriate to the theory of planned behaviour because Ajzen (1991) stated that perceived variables can be explained by beliefs. So, entrepreneurial self-efficacy can be seen as a powerful variable in explaining entrepreneurial intention. Finally, the context of collectivism and the importance of the family, salient people, especially parents, can have a significant impact on youths' career choice and this variable is expected to have direct effect on entrepreneurial intention (Tran, 2011). However, the results of our study indicate that although entrepreneurial intention is not directly influenced by subjective norms, it is indirectly affected by subjective norms through entrepreneurial self-efficacy, attitude towards entrepreneurship and perceived behavioural control $\left(\beta_{\text {indirect } S N-E I}=0.471, p\right.$-value $\left.<0.001\right)$. Moreover, subjective norms also have the indirect effects on attitude towards entrepreneurship ( $\beta_{\text {indirect } S N-A T E}=0.460, p$-value $<0.001)$ and perceived behavioural control $\left(\beta_{\text {indirect } S N-P B C}=0.199\right.$, $p$-value $\left.<0.001\right)$ via entrepreneurial self-efficacy. Thus, entrepreneurial self-efficacy plays the mediating role on the relationship between subjective norms and entrepreneurial intention. In addition, entrepreneurial intention is both directly and indirectly influenced by entrepreneurial self-efficacy $\left(\beta_{\text {total } E S E-E I}=0.893\right.$, $p$-value $\left.<0.001\right)$. So, in difference to Western countries, the cultural context of Vietnamese community, reference people (subjective norms) are expected to have dramatically and direct effects on business start-up intention. However, this result shows that subjective norms do not directly influence on entrepreneurial intention. Its results reflect that final-year students are able to be enough mature to make career choice by themselves. Although salient people cannot directly influence entrepreneurial intention, they play important role in building entrepreneurial self-efficacy $(\beta=0.343)$ and attitude toward entrepreneurship $(\beta=0.249)$ among Vietnamese students.

\section{Implications and recommendations}

This study is expected to provide contributions for entrepreneurship research and practices. In terms of entrepreneurship literature, the contributions of our study is indicated in some perspectives. First, the approval or non-approval from reference people (subjective norms) have not a direct effect on Vietnamese student's entrepreneurial intention. However, it has an indirect impact on entrepreneurial intention through entrepreneurial self-efficacy, attitude towards entrepreneurship and perceived behavioural control. In order words, entrepreneurial self-efficacy, attitude towards entrepreneurship and perceived behavioural control have mediated the relationship between subjective norms and entrepreneurial intention. Moreover, the results of our study also show that the relationship between entrepreneurial self-efficacy and entrepreneurial intention is mediated by attitude towards entrepreneurship and perceived behavioural control. Thus, two research questions have been answered clearly. In addition, this study has also proved that the application of the planned behavioural theory in the transitional economics context in Vietnam is totally fit and reasonable.

With regard to practices and implications, this study can contribute to entrepreneurship education at universities in Vietnam. First, the result shows the important role of "attitude towards entrepreneurship" in explaining business start-up intention, which allows us suggesting lecturers, educators and policy makers to find out solutions to influence strongly in students' positive attitude towards entrepreneurship. Lecturers often spend much time and efforts to lecture knowledge, skills and tools to students, however, "attitude" plays the key role in shaping students' entrepreneurial intention. Thus, lecturers should find the suitable teaching methods to improve students' positive attitude towards entrepreneurship, sharing successful experiences by actual entrepreneurs, for example, it can contribute to increase the positive attitude towards entrepreneurship among students. Secondly, entrepreneurial self-efficacy is also seen as a powerful variable, which has both direct and indirect effects in entrepreneurial intention. Thus, in case of considering entrepreneurial intention as the output of entrepreneurship education, the important problem is how to improve students' entrepreneurial self-efficacy. Wood and Bandura (1989) stress that there are four ways to strengthen students' entrepreneurial self-efficacy, including mastery experiences (perfor- 
mance successes), role models, social persuasion and physiological states. So, regarding the entrepreneurship education, doing small projects or extra-scholar or presenting successful stories of entrepreneurs or inviting entrepreneurs to share their start-up experiences may encourage students to believe about their entrepreneurial abilities and skills. Finally, although subjective norms do not influence the business startup intention, it has indirect effect in entrepreneurial intention through self-efficacy, attitude towards entrepreneurship and perceived behavioural control. Thus, social pressure cannot influence in entrepreneurial intention but it still plays the crucial role on shaping business start-up intention. University environments, including friends and lecturers, also can encourage students to run own business. Thus, fostering business start-up movement in universities (start-up club, successful stories of entrepreneurs, start-up contest...) can be considered the effective way to strengthen students' entrepreneurial intention.

Further research can take several directions. First, expansion of sample beyond Hanoi, Da Nang, Quy Nhon, Ho Chi Minh city may identify biases and yield new insights. Second, randomly sampled approach should be used to increase the significant level. Third, in addition to discover the mediating role of entrepreneurial self-efficacy in the relationship between subjective norms and entrepreneurial intention, it would be worthwhile to examine the moderating roles of subjective norms in the transitional economics of Vietnam. Finally, further researches should extent the research model by adding new variable such as gender, fields of study, entrepreneurship education, entrepreneurial ecosystem...in order to enrich and contribute to literature review and practices in entrepreneurship field.

\section{Appendix A}

Scales used in the final analyses:

\section{Entrepreneurial Intention}

I will make every effort to start and run my own firm

I am determined to create a firm in the future

I have a very seriously through of starting a firm

I have the firm intention to start a firm some day

Attitude Toward Entrepreneurship

A career as an entrepreneur is attractive for me

Being an entrepreneur would entail great satisfactions for me

Among various options, I would rather be an entrepreneur

Subjective Norm

If I decided to create a firm, my closest family would approve of that decision

If I decided to create a firm, my closest friends would approve of that decision

If I decided to create a firm, people who are important to me would approve of that decision

Perceived Behavioural Control

To start a firm and keep it working would be easy for me

I am prepared to start a viable firm

I can control the creation process of a new firm

I know the necessary practical details to start a firm

Entrepreneurial Self-Efficacy

I show great aptitude for creativity and innovation

I show great aptitude for leadership and problem-solving

I can develop and maintain favourable relationships with potential investors

I can see new market opportunities for new products and services

I can develop a working environment that encourages people to try out something new 


\section{References}

Ajzen, I. (1991). The theory of planned behaviour. Organizational Behaviour and Human Decision Processes, 50(2), 179-211.

Ajzen, I., \& Cote, N.G. (2008). Attitudes and the prediction of behaviour. In: Crano, W.D., Prislin, R., editors. Attitudes and Attitude Change. New York: Psychology Press. 289-311.

Al-Rafee, S., \& Cronan, T.P. (2006). Digital piracy: Factors that influence attitude toward behaviour. Journal of Business Ethics, 63(3), 237-259.

Autio, E., H. Keeley, R., Klofsten, M., Parker, G. C., \& Hay, M. (2001). Entrepreneurial intent among students in Scandinavia and in the USA. Enterprise and Innovation Management Studies, 2, 145-160.

Bandura, A. (1977). Social Learning Theory. Prentice Hall, Englewood Cliffs, NJ.

Bandura, A., Adams, N. E., Hardy, A. B., \& Howells, G. N. (1980). Tests of the generality of self-efficacy theory. Cognitive Theory and Research, 4(1), 39-66.

Bandura, A. (1986). The Social Foundations of Thought and Action. Englewood Cliffs: Prentice-Hall.

Bandura, A. (2001). Social cognitive theory: An agentic perspective. Annual Review of Psychology, 52, $1-26$.

Baron, R. A., \& Markman, G. D. (1999). Cognitive mechanisms: Potential differences between entrepreneurs and non-entrepreneurs. Frontiers of Entrepreneurship Research, 19.

Baum, J. R., Locke, E. A., \& Smith, K. (2001). A multidimensional model of venture growth. Academy of Management Journal, 44(2), 292-303.

Baughn, C. C., Cao, J.S.R., LE, L.T.M, Lim, V. A. \& Neupert, K.E (2006). Normative, Social and Cognitive predictors of entrepreneurial interest in China, Vietnam and the Philippines. Journal of Development Entreprenurship, 11(1), 57-77.

Bird, B. (1988). Implementing entrepreneurial ideas: The case for intention. Academy of management Review, 13(3), 442-453.

Chen, C. C., P. G. Greene \& A. Crick (1998). Does entrepreneurial self-efficacy distinguish entrepreneurs from managers? Journal of Business Venturing, 13, 295-316.

Chen, G., Gully, M. S., \& Eden, D. (2004). General self-efficacy and self-esteem: Toward theoretical and empirical distinction between correlated self-evaluations. Journal of Organizational Behaviour, 25, 375-395.

Cole, A.H. (1965). An approach to the study of entrepreneurship, in Aitken, H.G. (ed.), Explorations in enterprise, Harvard University Press, Cambridge, Mass, pp. 3044.

Fayolle, A., Gailly, B., \& Lassas-Clerc, N. (2006). Assessing the impact of entrepreneurship education programmes: a new methodology. Journal of European Industrial Training, 30(9), 701-720.

Hair, J.F.J., Anderson, R.E., Tatham, R.L., Black, W.C., (1998). Multivariate Data Analysis, 5th ed., Prentice Hall, Upper Saddle River, New Jersey.

Kettinger, W. J., \& Lee, C. C. (1995). Exploring a "gap" model of information services quality. Information Resources Management Journal (IRMJ), 8(3), 5-17.

Krueger, N. F. (1993). The impact of prior entrepreneurship exposure on perception of new venture feasibility and desirability. Entrepreneurship Theory and Practice, 18, 5-21.

Krueger, N. F. (2000). The cognitive infrastructure of opportunity emergence. Entrepreneurship Theory and Practice, 24(3), 5-23.

Krueger, N. F., Reilly, M. D., \& Carsrud, A. L. (2000). Competing models of entrepreneurial intentions. Journal of Business Venturing, 15(5), 411-432.

Krueger, N. F., Jr., \& Brazeal, D. V. (1994). Entrepreneurial potential and potential entrepreneurs. Entrepreneurship Theory \& Practice, 18, 91-104.

Kickul, J., Gundry, L. K., Barbosa, S. D. \& Whitcanack, L. (2009). Intuition versus analysis? Testing differential models of cognitive style on entrepreneurial self-efficacy and the new venture creation process, Entrepreneurship Theory \& Practice, 33(2), 439-453.

Kolvereid, L. (1996a). Organizational employment versus self-employment: Reasons for career intentions. Entrepreneurial Theory and Practice, 23(3), 23-31. 
Kolvereid, L. (1996b). Prediction of employment status choice intentions, Entrepreneurship Theory \& Practice, 21(1), 47-57.

Kolvereid, L., \& Isaksen, E. (2006). New business start-up and subsequent entry into self-employment. Journal of Business Venturing, 21, 866-885.

Reynolds, R.W., N.A. Rayner, T.M. Smith, D.C. Stokes and W. Wang (2002). An improved in situ and satellite SST analysis for climate. Journal of Climate, 15, 1609-1625.

Lee, L., Wong, P., Foo, M., \& Leung, A. (2011). Entrepreneurial intentions: the influence of organizational and individual factors. Journal of Business Venturing, 6(1), 124-136.

Liñán, F. (2008). Skill and value perceptions: How do they affect entrepreneurial intentions? International Entrepreneurship and Management Journal, 4(3), 257- 272.

Liñán, F., Santos, F. J. \& Fernández, J. (2011). The influence of perceptions on potential entrepreneurs, International Entrepreneurship and Management Journal, 7(3), 373-390.

Liñán, F., Nabi, G. \& Kueger, N. (2013). British and Spanish entrepreneurial intentions: A comparative study, La intención emprendedora en reino unido y españa: Un estudio comparativo, 33(1), 73-103.

Liñán, F. \& Chen, Y. W. (2009). Development and Cross-Cultural Application of a Specific Instrument to Measure Entrepreneurial Intentions. Entrepreneurship Theory and Practice, 33(3), 593-617.

Liñán, F. \& Chen, Y. W. (2006). Testing the Entrepreneurial Intention Model on a Two-Country Sample. Departament d'Economia de l'Empresa.

Lopez, S. J., \& Snyder C. R. (2011). The Oxford Handbook of Positive Psychology (2nd ed.). New York: Oxford University Press.

Markman, G. D., Balkin, D. B., \& Baron, R. A. (2002). Inventors and new venture formation: the effects of general self-efficacy and regretful thinking. Entrepreneurship Theory \& Practice, 27(2), 149-166.

Miranda, F. J., Chamorro-Mera, A., Rubio, S. (2017). Academic entrepreneurship in Spanish university: An analysis of determinants of entrepreneurial intention. European Research on Management and Business Economics, 23, 113-222.

Neto, R., Rodrigues, V., Steward, D, Xiao, A. \& Snyder, J. (2018). The influence of self-efficacy on entrepreneurial behaviour among K-12 teacher. Teaching and Teacher Education, 72, 44-53.

Nwanzu, C. L. \& Babalola, S.S. (2019). Examining psychological capital of optimism, self-efficacy and selfmonitoring as predictors of attitude towards organizational change. International Journal of Engineering Business Management, 11, 1-12.

Obschonka, M., Silbereisen, R. K., \& Schmitt-Rodermund, E. (2010). Entrepreneurial intention as developmental outcome. Journal of Vocational Behaviour, 77(1), $63-72$.

Preacher, K. J., \& Hayes, A. F. (2004). SPSS and SAS procedures for estimating indirect effects in multiple mediator models. Behaviour Research Methods, Instruments, and Computers, 36, 717-731.

Preacher, K. J., \& Hayes, A. F. (2008). Asymptotic and resampling strategies for assessing and comparing indirect effects in multiple mediator models. Behaviour Research Methods, 40, 879-891.

Saraih, U., Aris. A., Mutalib, S., Ahmad, T., Abdullah, S. \& Amlus, M. (2018). The influence of Selfefficacy on Entrepreneurial Intention among Engineering Students. MUCET (Conference), https://doi.org/10.1051/matecconf/201815005051.

Schlaegel, C., \& Koenig, M. (2014). Determinants of entrepreneurial intent: A metaanalytic test and integration of competing models. Entrepreneurship Theory \& Practice, 38(2), 291-332.

Segal, G., Borgia, D., \& Schoenfeld, J. (2005). The motivation to become an entrepreneur. International Journal of Entrepreneurial Behaviour \& Research, 11(1), 42-57.

Shinnar, R. S., Hsu, D. K. \& Powell, B. C. (2014). Self-efficacy, entrepreneurial intentions, and gender: Assessing the impact of entrepreneurship education longitudinally. The International Journal of Management Education, 12, 561-570.

Silveira-Pérez, Y., Cabeza-Pullés, D., \& Fernández-Pérez, V. (2016). Emprendimiento: perspectiva cubana en la creación de empresas familiares. European Research on Management and Business Economics, 22(2), 70-77. 
Solesvik, M. Z., Westhead, P., Kolvereid, L. \& Matlay, H. (2012). Student intentions to become selfemployed: The Ukrainian context, Journal of Small Business and Enterprise Development, 19(3), 441-460.

Sobel, M. E. (1986). Some new results on indirect effects and their standard errors in covariance structure models. In S. Leinhart (Ed.), Sociological Methodology (pp. 159-186). San Francisco: JosseyBass.

Tavousi, M., Hidarnia, A. R., Montazeri, A., Hajizadeh, E., Taremian, F., \& Ghofranipour, F. (2009). Are perceived behavioural control and self-efficacy distinct constructs? European Journal of Scientific Research, 30(1), 146-152.

Tran, V.T. (2011). La perception de la carrière entrepreneuriale des étudiants, le cas du Vietnam. Journal of Social Management (Zeitschrift für Sozialmanagement, ISSN 1612-8389), 9, Special Issue: Entrepreneurship.

Tsai, K. H., Chang, H.C. Peng, C.Y. (2014). Extending the link between entrepreneurial self-efficacy and intention: A moderated mediation model. International Entrepreneurship and Management Journal, 12, 445-463.

Utamin, C. W. (2017). Attitude, subjective norms, perceived behaviour, entrepreneurship education and self-efficacy towards entrepreneurial intention university student in Indonesia. European Research Studies Journal, 20(24), 475-495.

Wood, R., \& Bandura, A. (1989). Social cognitive theory of organizational management. Academy of management Review, 14(3), 361-384.

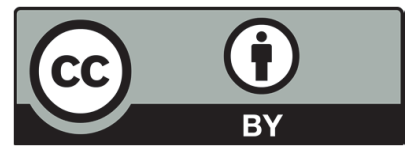

(C) 2019 by the authors; licensee Growing Science, Canada. This is an open access article distributed under the terms and conditions of the Creative Commons Attribution (CCBY) license (http://creativecommons.org/licenses/by/4.0/). 